however, their impact was negative in 2019, when application Quadrostim decreased the 1000 -seed weight to $33.8 \mathrm{~g}$ vs. $41 \mathrm{~g}$ in the control, but this regulator did not affect the test weight, which was higher than the control value (227 g/L vs. $205 \mathrm{~g} / \mathrm{L}$ in the control). On average, the test weight in the PGR experiments was more dependent on the year, ranging within $278-272 \mathrm{~g} / \mathrm{L}(248 \mathrm{~g} / \mathrm{L}$ in the control).

Conclusions. The treatment with the growth regulators was found to be the most effective for the SKh808A line. The gain in the yield ranged from $0.4 \mathrm{t} / \mathrm{ha}$ to $0.7 \mathrm{t} / \mathrm{ha}$. depending on the growth regulator. The 1000-seed weight increased by $6.7 \mathrm{~g}$ under the Quadrostim influence, and the test weight - by $403 \mathrm{~g} / \mathrm{L}(379 \mathrm{~g} / \mathrm{L}$ in the control) when Ecostim was applied.

Fulvital Plus and Quadrostim were the most effective growth regulators. The effect of Ecostim varied depending on the soil and climatic conditions and the line genotypes. The most effective application of the growth regulators on sterile analogues of self-pollinated sunflower lines may be due to CMS and different physiological characteristics of these lines.

Key words: seed production, sunflower lines, growth regulators, yield, hybrids, heterosis.

\title{
ADAPTABILITY OF SUNFLOWER HYBRIDS ORIGINATED AT THE VNIS IN THE UKRAINIAN CONDITIONS
}

Sharypina Ya., Borovska I., Parii Ya., Parii Yu., Babych V., Nakonechna M., Kostenko Yu., Sirko A. LLC «Ukrainian Scientific Institute of Plant Breeding», Ukraine

The article presents the results of an analysis of ecological testing data of new sunflower hybrids of LLC "Ukrainian Scientific Institute of Plant Breeding (VNIS)" (Kiev, Ukraine), placed in eight environmental points in the Ukraine. The diversity of agro-climatic conditions and their distribution throughout the year relative to the regions made it possible to fully reveal the potential of hybrids in terms of yield capacity, as well as to assess their ecological plasticity and stability. Prospective sunflower hybrids were identified that showed high yield capacity according to the results of the study in eight points: 2,84-3,43 t/ha among hybrids resistant to the herbicides containing tribenuron-methyl (SU) and 2,86-3,33 t/ha among hybrids resistant to the herbicides of the imidazolinone group (IMI).

The prospective hybrids based on the results of studying their ecological plasticity and stability are recommended for cultivation in certain regions of the Ukraine.

Key words: sunflower, hybrid, seed yield, environment trials, adaptability, plasticity

Introduction. Sunflower is one of the main oil crops in the world. Over the past 50 years breeders have achieved significant success in augmenting major traits that are economically significant for humans - yield capacity, oil content and resistance to diseases [1].

In Ukraine, in the last decade, there has been an upwair trend in the sunflower oil export. The global export of sunflower oil has increased due to a combination of numerous offers from the main supplier countries and the active demand from key importers. The main exporters of sunflower oil (Ukraine, Russia) provide $76.0 \%$ of the total world product export to the market [2-4].

Rapid changes in the sunflower assortment in the market of breeding products offered by competing manufacturers prompt researchers to seek accelerated and effective methods for identifying the best genotypes.

(c) Ya. Sharypina, I. Borovska, Ya. Parii, Yu. Parii, V. Babych, M. Nakonechna, Yu. Kostenko, A. Sirko. 2020. ISSN 1026-9959. Селекція і насінництво. 2020. Випуск 117. 
The experience in industrial sunflower cultivation indicates that it is possible to achieve yields over $3.0 \mathrm{t} / \mathrm{ha}$. However, such a level of the main trait of the crop is only fulfilled, if a hybrid is bred with due account for its adaptability and specific soil and climatic conditions of cultivation.

The territory of Ukraine exceeds 600 thousand $\mathrm{km}$ and is characterized, despite the prevalence of a temperate continental climate, by significant differences in the climate humidity, temperature, and, accordingly, the growing period lengths of major crops [5]. Therefore, to introduce new sunflower hybrids into production, it is necessary to objectively assess their genetic potential and competability and to determin the environmental orientation, i..e. the growing zone [6].

Environmental trials assessing the environmental plasticity and stability of hybrids is one of the most justified methods for studying the reaction norm to the growing area $[7,8]$.

Purpose - to select high-yielding promising sunflower hybrids originated at the VNIS for cultivation in certain regions of Ukraine.

Material and methods. The environmental trials of hybrids were carried out in 8 regions of Ukraine (Kyiv, Poltava, Cherkasy, Dnipropetrovsk, Vynnytsia, Ternopil, Mykolaiv, and Kherson regions) in 2019.

Hybrids and their parents were previously studied for 3 years (2016-2018) at the experimental breeding base of the VNIS (Kyiv region, Obukhiv district, Bezymianne village) by major agronomic traits: morphological (plant height, calathidium diameter and incline), phenological (the entire growing period and individual developmental phases lenghts), biochemical (oil content and composition) characteristics as well as resistance to diseases and herbicides.

299 sunflower hybrids were tested in the environmental trials. A significant amount of the material under investigation was due to the long-term breeding process under the scope of several VNIS's breeding programs, as well as a possibility of accelerating the creation of lines and hybridization in winter nurseries in Chile.

The accessions were assigned to 2 experiments, depending on resistance to a certain herbicide. Based on a set of characteristics, 138 sunflower hybrids resistant to imidazolinone (IMI herbicides) and 161 hybrids resistant to tribenuron-methyl (SU)-containing herbicides were selected. The best foreign hybrids (SY Sumiko, P64LE25, NK Neoma, Genesis ES) were taken as check accessions.

The randomized accessions were sown in duplicate in blocks of 23 accessions each, also each block had 2 check accessions. Block randomization was used to generate equivalent groups. The conditions were randomly distributed within the block. The total plot area was $20 \mathrm{~m}^{2}$; the measurement plot area was $10 \mathrm{~m}^{2}$. The pre-harvest plant density in the zone with sufficient humidification was 65,000 plants per hectare, in the zone with water deficit - 55,000 plants per hectare.

Sowing of the experimental plots [9], phenological observations and measurements were carried out in accordance with generally accepted for sunflower methods [9].

Harvesting was carried out by a Haldrup CTS-95 Twin Shaker breeding harvester with software provided by the manufacturer. During harvesting, the hybrid yield per plot (kg), water content in seeds, and test weight were determined, and samples for further biochemical analyses were collected. In the laboratory conditions, the oil content and the amount of oleic acid in the samples were determined on a Spinlock SLK-200 magnetic resonance spectrometer.

The environmental plasticity and stability indices were calculated by S.A. Eberhart and W.A. Rassel's method [10] described by V.Z. Pakudin and L.M. Lopatina [11]. The calculated coefficient of linear regression $\left(b_{i}\right)$ characterizes the environmental plasticity of a hybrid, and the mean-square deviation from the regression line $\left(\mathrm{S}_{\mathrm{i}}{ }^{2}\right)$ characterizes the hybrid stability in various environments, where $\bar{X}$ is the mean value of the trait across all genotypes and $X_{i}$ is the mean value of the trait of the $I^{\text {th }}$ t genotype across the years and sites.

The genotypes were categorized by anvironmental plasticity coefficients $\left(b_{i}\right)$ in three groups: highly plastic $b_{i}>(1+\sigma)$ - the trait susceptibility in the genotype to changes in growing conditions is ouside the susceptibility range of the entire sample of hybrids, and the trait level under favorable conditions (i.e., under conditions of maximum expression of the trait) increases; medium plastic $b_{i}=(1 \pm \sigma)$ - the susceptibility to varying environmental conditions is similar to the average sussceptibility in the sample of the studied hybrids; low plastic $b_{i}=(1-\sigma)$ - the trait value related to the other genotypes decreases under more favorable conditions. 
In order to determine the distinctive features of the regions by humidification, the H.T. Selyaninov hydrothermal coefficient (HTC) was calculated as the ratio of the precipitation amount for the period to the sum of temperatures above $10 \mathrm{C}$ for the same period, multiplied by a constant coefficient of 0.1 [12].

Cluster analysis was carried out by complete-linkage clustering on Euclidean distances. The experimental data were processed by methods of variation statistics, regression and variance analyses [13] in the Microsoft Office Excel 2010 and Statistics 10.0 applications.

Result and discussion. In Ukraine, four agro-climatic zones are distinguished, gradually turning one into another. A warm zone with sufficient humidification is located in the northwestern part. To the south-east of it, a warm zone with medium humidification stretches. Farther in the southeast direction, there is a very warm arid zone, and the entire southern part of the country is located in a moderately hot arid zone.

The temperature mode, the total amount of precipitation, their distribution across regions and seasons significantly influence on the climate formation [14]. Quantitative assessment of the spatial distribution of these indicators is based on the hydrothermal coefficient [15], which, in our opinion, quite adequately describes the differences in the agro-climatic resources of each site of the environmental trials used in the study to assess the adaptive potential of new sunflower hybrids.

Table 1

HTC in the trial sites

\begin{tabular}{lcccccc}
\hline \multicolumn{1}{c}{ Point } & April & May & June & July & August & September \\
\hline Kherson & 1,02 & 0,80 & 0,69 & 0,70 & 0,51 & 0,73 \\
Mykolayiv & 0,95 & 0,78 & 0,78 & 0,74 & 0,52 & 1,57 \\
Vinnytsia & 1,82 & 1,39 & 1,62 & 1,62 & 1,15 & 0,81 \\
Dnipro & 1,25 & 0,79 & 0,92 & 0,74 & 0,58 & 1,12 \\
Cherkasy & 2,43 & 0,86 & 1,10 & 1,14 & 0,86 & 1,04 \\
Ternopil & 2,26 & 1,65 & 1,55 & 1,58 & 1,18 & 0,71 \\
Kyiv & 2,24 & 0,87 & 1,16 & 1,16 & 0,89 & 0,94 \\
Poltava & 2,08 & 0,83 & 0,96 & 1,06 & 0,85 & 1,03 \\
\hline
\end{tabular}

Cluster analysis made it possible to group the hybrid trial sites by similarity of the climatic conditions during the growing period of sunflower (Fig. 1).

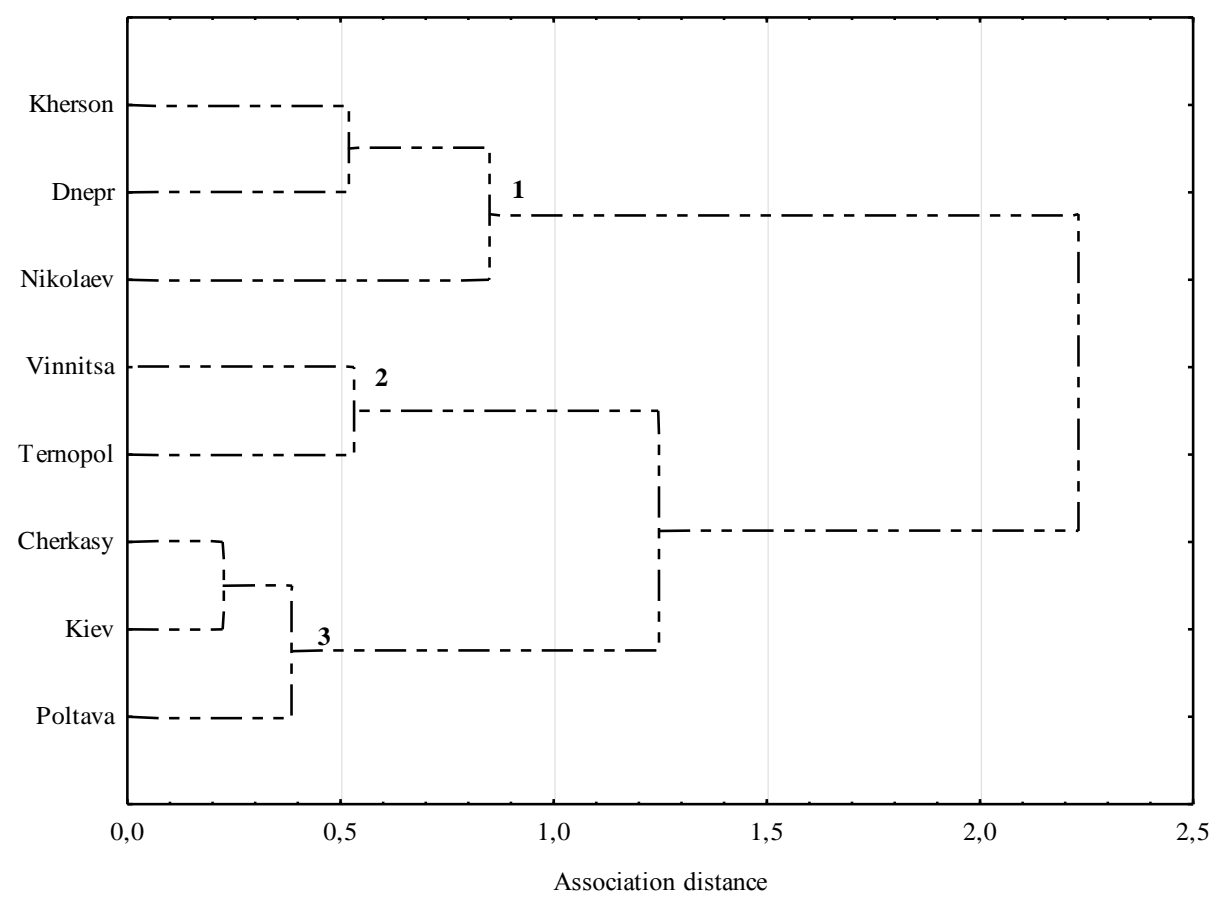

Fig. 1. Analysis of the climate similarity between the trial sites 
Thus, the lowest HTC values, which correspond to the least favorable conditions for growing sunflower, were recorded in the sites conventionally designated as "Kherson", "Dnipro" and "Mykolaiv" (group 1). The opposite to the previous ones are "Poltava", "Kyiv" and "Cherkasy" - the sites grouped by HTC in group 3, with the most favorable conditions for growing sunflower. Similar conditions, but intermediate between the two previous groups, were in the sites "Vinnytsia" and "Ternopil" (group 2).

Calculation of the environmental indices revealed that the best conditions for high yields from the IMI hybrids were at the environments "Kyiv" $\left(I_{i}=1.02\right)$ and "Cherkasy" $\left(I_{i}=0.98\right)$, and the least favorable - at "Poltava" $\left(I_{i}=-0.86\right)$ and "Kherson" $\left(I_{i}=-1.41\right)$ (Table 2).

Table 2

Characterization of the most productive IMI sunflower hybrids by adaptability

\begin{tabular}{|c|c|c|c|c|c|c|c|c|c|c|c|}
\hline \multirow[b]{2}{*}{ Source ID } & \multicolumn{9}{|c|}{ Yielding, $\mathrm{t} / \mathrm{ha}$} & \multicolumn{2}{|c|}{ Adaptability parameters } \\
\hline & : & 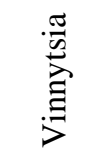 & $\frac{\mathbb{\pi}}{\stackrel{\Xi}{\Xi}}$ & 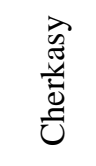 & $\vec{\lambda}$ & 号 & 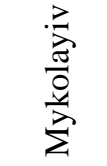 & 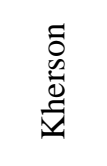 & $\mathrm{X}_{\mathrm{i}}$ & $b_{i}$ & $\mathrm{~S}_{\mathrm{i}}{ }^{2}$ \\
\hline \multicolumn{12}{|c|}{ high - plastic } \\
\hline UA-076 & 2,60 & $3,83 *$ & - & $3,93 *$ & $4,85^{*}$ & $2,88 *$ & 2,17 & 1,34 & $3,08^{*}$ & 1,40 & 6,74 \\
\hline UA-017 & 2,70 & 3,32 & - & $4,73 *$ & $3,96^{*}$ & $2,90 *$ & $2,70^{*}$ & 1,09 & $3,06^{*}$ & 1,34 & 6,51 \\
\hline UA-100 & $3,44 *$ & $3,80 *$ & - & 3,83 & $4,16^{*}$ & $3,02 *$ & 1,83 & 1,24 & $3,04 *$ & 1,33 & 6,59 \\
\hline UA-057 & 2,55 & 2,63 & - & $4,63 *$ & $4,43 *$ & 2,12 & $2,61 *$ & 1,33 & $2,90 *$ & 1,30 & 5,69 \\
\hline UA-059 & $3,24 *$ & 3,18 & - & 3,65 & $4,15^{*}$ & $2,98 *$ & 1,89 & 0,97 & $2,87 *$ & 1,30 & 6,19 \\
\hline UA-028 & $3,04 *$ & $3,67 *$ & - & 3,32 & $5,18 *$ & $3,69 *$ & $2,74^{*}$ & 1,34 & $3,28 *$ & 1,27 & 6,80 \\
\hline UA-066 & 2,70 & $3,44 *$ & - & 3,53 & $4,46^{*}$ & $2,86^{*}$ & $2,29 *$ & 1,37 & $2,95^{*}$ & 1,20 & 5,37 \\
\hline UA-101 & \multicolumn{10}{|c|}{ medium - plastic } & 5,26 \\
\hline UA-016 & 1,97 & - & - & $4,29 *$ & $5,81 *$ & $3,09 *$ & $2,92 *$ & $1,93 *$ & $3,33 *$ & 1,05 & 7,73 \\
\hline UA-021 & 2,81 & - & - & $4,33^{*}$ & $4,69 *$ & $3,24 *$ & $2,54 *$ & $1,57 *$ & $3,20 *$ & 0,99 & 6,94 \\
\hline UA-118 & $3,64 *$ & $4,31 *$ & - & 3,71 & 3,63 & 2,74 & $2,57 *$ & 1,39 & $3,14^{*}$ & 1,13 & 5,80 \\
\hline UA-129 & $3,80 *$ & $3,62 *$ & - & 3,85 & 3,79 & 2,64 & $2,32 *$ & $1,93 *$ & $3,13^{*}$ & 1,01 & 4,65 \\
\hline UA-024 & 2,65 & 3,21 & - & 3,71 & $4,59 *$ & $3,49 *$ & $2,33^{*}$ & $1,85^{*}$ & $3,12 *$ & 1,10 & 4,93 \\
\hline UA-103 & $3,43 *$ & 2,97 & - & 3,73 & $4,04 *$ & $3,51 *$ & $2,45^{*}$ & 1,20 & $3,05^{*}$ & 1,14 & 5,65 \\
\hline \multicolumn{12}{|c|}{ low - plastic } \\
\hline UA-044 & $3,19 *$ & - & 1,95 & $4,30 *$ & $4,23 *$ & 2,34 & $2,49 *$ & $1,50 *$ & 2,86 & 0,62 & 3,27 \\
\hline UA-108 & $3,20 *$ & 3,08 & $2,17^{*}$ & $4,05^{*}$ & 3,36 & $3,24 *$ & $2,54^{*}$ & $1,61 *$ & $2,91^{*}$ & 0,62 & 1,45 \\
\hline UA-084 & 2,76 & - & - & 3,63 & 3,94 & $2,85^{*}$ & 2,27 & $2,12 *$ & $2,93^{*}$ & 0,61 & 4,31 \\
\hline UA-011 & 2,61 & - & $2,25^{*}$ & $4,56^{*}$ & 3,81 & $3,14 *$ & $2,37 *$ & $1,70 *$ & $2,92 *$ & 0,49 & 2,88 \\
\hline UA-135 & $3,78^{*}$ & - & $2,16^{*}$ & $4,25^{*}$ & 3,20 & $3,13^{*}$ & 2,08 & $1,57 *$ & $2,88 *$ & 0,41 & 2,87 \\
\hline UA-015 & 2,81 & - & $2,30 *$ & $4,19 *$ & 3,53 & $3,36^{*}$ & $2,52 *$ & $1,60 *$ & $2,90 *$ & 0,37 & 2,54 \\
\hline $\bar{X}$ & 2,90 & 3,32 & 1,97 & 3,81 & 3,85 & 2,78 & 2,21 & 1,42 & 2,83 & 0,89 & 4,73 \\
\hline$\sigma$ & - & - & - & - & - & - & - & - & - & 0,26 & 1,71 \\
\hline $\mathrm{LTD}_{05}$ & 0,09 & 0,09 & 0,08 & 0,09 & 0,10 & 0,07 & 0,07 & 0,04 & 0,04 & - & - \\
\hline Environmental indices $\left(I_{i}\right)$ & 0,07 & 0,49 & $-0,86$ & 0,98 & 1,02 & $-0,05$ & $-0,62$ & $-1,41$ & - & - & - \\
\hline
\end{tabular}

The adaptability of the hybrids to various agro-climatic conditions was assessed by indicators of environmental plasticity and stability indices of their yield capacity - the main selection criterion.

In general, $44.0 \%$ of the IMI hybrids gave significantly high yields ranging within 2.86$3.40 \mathrm{t} / \mathrm{ha}$. Some of the most productive IMI hybrids, namely UA-108, UA-011, UA-115, UA-135, 
UA-084, and UA-044 (2.83-2.93 t/ha), were identified as the least susceptible to differences in the environmentalconditions of cultivation, as their envirinmental plasticity coefficients were low $\left(b_{i}=0.37-0.62\right)$.

Out of the IMI sunflower hybrids, UA-011, UA-015 and UA-135 showed high yield stability at the trial sites $\left(\mathrm{S}_{\mathrm{i}}{ }^{2}=1.45-2.88\right)$. Out of the most productive sunflower hybrids, 8 (UA017, UA-028, UA-057, UA-059, UA-066, UA-076, UA-100, and UA-101) were distinguished by high environmental plasticity coefficient $\left(b_{i}=1.18-1.60\right)$. These hybrids, according to the data averaged across the trial sites, gave the highest seed yields in the experiment $-2.86-3.28 \mathrm{t} / \mathrm{ha}$.

The group of medium - plastic IMI hybrids with the environmental plasticity coefficient ranging from $b_{i}=1.15$ to $b_{i}=0.63$ and optimal norms of reaction to the climatic conditions in the trial sites, includes $31.2 \%$ of the accessions. Among them, the highest yields of $3.05-3.33$ t/ha were obtained from hybrids UA-103, UA-016, UA-118, UA-021, UA-024, and UA-129 $\left(b_{i}=\right.$ 0.99-1.14).

A somewhat different pattern is observed with the influence of environmental conditions on the yields of the SU sunflower hybrids under investigation. Thus, the best conditions for high yields from such hybrids were in the site "Cherkasy" $\left(I_{i}=1.43\right)$ (Table 3$)$.

Table 3

Characterization of the most productive SU sunflower hybrids by adaptability Yielding, t/ha Adaptability parameters

\begin{tabular}{|c|c|c|c|c|c|c|c|c|c|c|c|}
\hline \multirow[b]{2}{*}{ Source ID } & \multicolumn{9}{|c|}{ Yielding, $\mathrm{t} / \mathrm{ha}$} & \multicolumn{2}{|c|}{ Adaptability parameters } \\
\hline & $\begin{array}{l}\overline{\bar{z}} \\
\stackrel{0}{0} \\
\stackrel{0}{=}\end{array}$ & 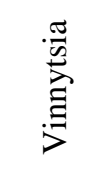 & 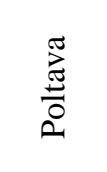 & 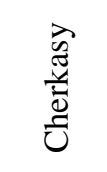 & $\vec{\lambda}$ & $\stackrel{\stackrel{0}{\mathscr{Z}}}{\stackrel{\Xi}{\Xi}}$ & 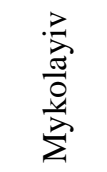 & $\begin{array}{l}\tilde{0} \\
\overline{0} \\
\bar{\Xi}\end{array}$ & $\mathrm{X}_{\mathrm{i}}$ & $b_{i}$ & $\mathrm{~S}_{\mathrm{i}}^{2}$ \\
\hline \multicolumn{12}{|c|}{ high - plastic } \\
\hline UA-167 & $3,70 *$ & $3,42 *$ & - & $4,31 *$ & $5,17^{*}$ & $3,81^{*}$ & $2,48^{*}$ & 1,09 & $3,43 *$ & 1,49 & 1,23 \\
\hline UA-181 & $3,62 *$ & $3,57 *$ & - & 4,08 & $4,00 *$ & $3,23^{*}$ & $2,31 *$ & 0,56 & $3,05^{*}$ & 1,48 & 0,69 \\
\hline UA-274 & 2,92 & $3,92 *$ & - & $4,66^{*}$ & $3,67 *$ & 2,42 & 2,24 & 1,14 & $3,00 *$ & 1,46 & 0,56 \\
\hline UA-227 & $3,38 *$ & $4,01 *$ & - & $4,78^{*}$ & $3,40 *$ & $2,86^{*}$ & $2,71 *$ & 1,21 & $3,19 *$ & 1,44 & 0,67 \\
\hline UA-154 & 2,97 & $3,38 *$ & - & $4,32 *$ & $3,83 *$ & $3,42 *$ & $2,47 *$ & 1,09 & $3,07 *$ & 1,33 & 0,71 \\
\hline UA-202 & $3,80 *$ & $3,60 *$ & - & $4,24 *$ & 3,18 & $3,10^{*}$ & 2,21 & 1,25 & $3,05^{*}$ & 1,30 & 0,71 \\
\hline \multicolumn{12}{|c|}{ medium - plastic } \\
\hline UA-288 & $3,32 *$ & - & - & 4,14 & $4,48 *$ & $3,70 *$ & $2,37 *$ & $1,62 *$ & $3,27 *$ & 0,95 & 3,50 \\
\hline UA-165 & $3,59 *$ & $3,42 *$ & $2,58^{*}$ & $4,50 *$ & $4,01 *$ & $3,13^{*}$ & $2,65^{*}$ & 1,06 & $3,12 *$ & 1,01 & 0,12 \\
\hline UA-204 & $3,98 *$ & - & - & $4,78^{*}$ & 2,72 & $3,29 *$ & 2,05 & $1,71^{*}$ & $3,09 *$ & 0,99 & 3,19 \\
\hline UA-147 & 3,03 & $3,32 *$ & $2,53 *$ & 4,06 & $4,10 *$ & $3,28^{*}$ & $2,69 *$ & 1,22 & $3,03^{*}$ & 0,84 & 0,17 \\
\hline UA-289 & $3,52 *$ & - & $2,12^{*}$ & $4,98 *$ & $3,72 *$ & $3,21^{*}$ & $2,65^{*}$ & 0,96 & $3,02 *$ & 0,90 & 2,22 \\
\hline UA-293 & $3,09 *$ & - & $1,77^{*}$ & $4,74 *$ & $4,28 *$ & $3,65^{*}$ & $2,27 *$ & 1,18 & $3,00 *$ & 0,89 & 2,31 \\
\hline \multicolumn{12}{|c|}{ low - plastic } \\
\hline UA-247 & 2,84 & - & $2,01^{*}$ & $4,47 *$ & $3,54 *$ & $3,09^{*}$ & $2,62 *$ & $1,35^{*}$ & $2,85^{*}$ & 0,65 & 1,87 \\
\hline UA-234 & $3,51 *$ & - & $2,22 *$ & $4,34 *$ & $3,40 *$ & $2,98^{*}$ & $2,55^{*}$ & $1,38^{*}$ & $2,91 *$ & 0,61 & 1,89 \\
\hline UA-150 & $3,17^{*}$ & - & $2,57 *$ & 3,98 & $3,69 *$ & $2,99 *$ & 2,11 & $1,35^{*}$ & $2,84^{*}$ & 0,52 & 1,84 \\
\hline$\overline{\mathrm{X}}$ & 3,01 & 3,19 & 1,71 & 4,11 & 3,22 & 2,59 & 2,21 & 1,22 & 2,68 & 0,93 & 0,94 \\
\hline$\sigma$ & - & - & - & - & - & - & - & - & - & 0,24 & 0,86 \\
\hline $\mathrm{LTD}_{05}$ & 0,07 & 0,11 & 0,06 & 0,06 & 0,12 & 0,09 & 0,06 & 0,04 & 0,04 & - & - \\
\hline Environmental indices $\left(I_{i}\right)$ & 0,34 & 0,52 & $-0,96$ & 1,43 & 0,55 & $-0,09$ & $-0,46$ & $-1,46$ & - & - & - \\
\hline
\end{tabular}

The conditions in the trial sites "Kyiv" and "Vinnytsia" were almost identical $\left(I_{i}=0.55\right.$ and $I_{i}=0.52$, respectively). The least favorable conditions, like for the IMI hybrids, also formed in the sites "Poltava" $\left(I_{i}=-0.96\right)$ and "Kherson" $\left(I_{i}=-1.46\right)$. 
Significantly high yields of seeds from the SU hybrids were given by $40.0 \%$ of the accessions. Among them, hybrids UA-150, UA-234, and UA-247 with seed yields of 2.84-2.91 t/ha were the least susceptible to fluctuations in the environmental conditions $\left(b_{i}=0.52-0.66\right)$.

Out of the 65 most productive hybrids, 16 had the highest environmental plasticity coefficients $\left(b_{i}=1.16-1.49\right)$. These hybrids, according to the data averaged across the trial sites, showed the highest level of the studied trait in the experiment $-2.73-3.43 \mathrm{t} / \mathrm{ha}$. The Table summarizes the characteristics of the six best of them (UA-154, UA-167, UA-181, UA-202, UA-227, and UA-274).

Out of $25.5 \%$ of medium - plastic SU hybrids $\left(b_{i}=0.74-1.15\right)$, the best results judging by the highest yields in this group of accessions (3.0-3.27 t/ha) were given by UA-147, UA-165, UA-204, UA-288, UA-289, and UA-293 $\left(b_{i}=0.89-1.01\right)$.

Conclusion. The environmental trials at the eight environments of Ukraine enabled us to conducct adaptability-based identification of the promising high-yielding hybrids resistant to herbicides containing tribenuron-methyl (SU) (2.84-.43 t/ha) and resistant to imidazolinone (IMI) herbicides (2.86-3.33 t/ha) and to recommend them for growing in appropriate environmental conditions.

In favorable soil and climatic conditions, highly plastic hybrids that are responsive to environmental conditions can fully manifest their yield potential. In regions of insufficient humidification, hybrids with an optimal response to environmental conditions (medium plastic) and hybrids with poor responsiveness to environmental conditions (low plastic) will give high yields.

Further research in large-scale trials and experimental production plantings under various soil and climatic conditions of Ukraine is planned on the selected sunflower hybrids.

\section{References}

1. Vear F. Changes in sunflower breeding over the last fifty years. OCL 2016; 23(2): D202. DOI: $10.1051 / \mathrm{ocl} / 2016006$.

2. URL: https://elevatorist.com/novosti/9064-eksport-podsolnechnogo-masla-iz-ukrainyi-v2018-19-mg-vyiros-na-14.

3. URL: 24tv.ua/ru/jeksport_ukrainy_2019_v_es_top_produktov_kotorye_jeksportiruet_ ukraina_n1197336.

4. Over $95 \%$ of the oil produced in Ukraine was exported. URL: http://agroportal.ua/news/ukraina/bolee-95-proizvedennogo-v-ukraine-masla-ushlo-naeksport/ (date of appeal: 29.01.2020).

5. Makliak KM. Methodological bases of sunflower breeding for heat resistance. [dissertation]. Plant Production Institute nd. a. VYa Yuriev of NAAS, Kharkiv. 2017.

6. Kolomatska VP, Kyrychenko VV, Syvenko VI, Leonova NM. The level and variability of yield of sunflower hybrids in the conditions of the Eastern part of the Forest-Steppe of Ukraine. Visnyk tsentru naukovogo zabezpechennia APV Kharkivskoyi oblasti. 2016; 21 : $158-166$.

7. Urumbayev K, Miklič V, Almishev U, Ovuka J. Testing of some NS-sunflower hybrids in the Northeast of Kazakhstan. Helia. 2017; 40(67): 211-222. DOI: 10.1515/helia-2017-0013.

8. Cvejić S, Jocić S, Mladenov V, Banjac B, Radeca L, Jocković M, Marjanović AJ, Miladinović D, Miklič V. Selection of sunflower hybrids based on stability across environments. Genetika. 2019; 51(1): 81-92. DOI: 10.2298/GENSR1901081C.

9. Škorić D, Seiler GJ, Zhao Liu et al. Genetics and breeding of sunflower. Genetics and selection of sunflower. Kharkiv : Serbian Academy of Sciences and Arts. Association «Selection and seed production of sunflower», 2015. $540 \mathrm{p}$.

10. Eberhart SA, Russel WA. Stability parameters for comparing varieties. Crop. Sci. 1966; 6(1): 36 40.

11. Pakudin VZ, Lopatina LM. Assessment of environmental plasticity and stability of agricultural crop varieties. Selskokhoziajstvennaia biologiya. 1984; 4: 109-113. 
12. Liashenko GV. Agroclimatic zoning of Ukraine. Ukrainian Hydrometeorological Journal. 2008; 3: 98-108.

13. Dospekhov BA. Planning field experience and statistical processing of its data. Moscow: Kolos, 1972. $207 \mathrm{p}$.

14. Climat data. URL : https://ru.climate-data.org/европа/украина.

15. Liashenko GV. Methodological aspects of application of GIS - technologies upon agroclimatic zoning of territories. URL: http://dspace.nbuv.gov.ua/bitstream/handle/ 123456789/98283/30-Lyashenko.pdf? sequence=1.

\section{Список використаних джерел}

1. Vear F. Changes in sunflower breeding over the last fifty years. OCL. 2016. № 23 (2). D202. DOI: $10.1051 /$ ocl/2016006.

2. Мировой экспорт подсолнечного масла за сезон 2018/19. Електронний ресурс : URL: https://elevatorist.com/novosti/9064-eksport-podsolnechnogo-masla-iz-ukrainyi-v-2018-19mg-vyiros-na-14.

3. Експорт України 2019. URL: 24tv.ua/ru/jeksport_ukrainy_2019_v_es_top_produktov_ kotorye_jeksportiruet_ukraina_n1197336.

4. Более $95 \%$ произведенного в Украине масла ушло на экспорт. URL: http://agroportal.ua/news/ukraina/bolee-95-proizvedennogo-v-ukraine-masla-ushlo-naeksport/.

5. Makliak K.M. Methodological bases of sunflower breeding for heat resistance. Автореф. дис. ... док. с.-г.н., 06.01.05 - селекція і насінництво. Інститут рослинництва ім. В.Я. Юр'єва НААН, Харків, 2017. 51 с.

6. Коломацька В.П., Кириченко В.В., Сивенко В.І., Леонова Н.М. Рівень та мінливість урожайності гібридів соняшнику в умовах Східної частини Лісостепу України. Вісник ЦНЗ АПВ Харківської області. 2016. Вип. 21. С. 158-166.

7. Urumbayev K., Miklič V., Almishev U., Ovuka J. Testing of some NS-sunflower hybrids in the Northeast of Kazakhstan. Helia. 2017. № 40 (67). P. 211-222. DOI: 10.1515/helia-20170013.

8. Cvejić S., Jocić S., Mladenov V., Banjac B., Radeca L., Jocković M., Marjanović A.J., Miladinović D., Miklič V. Selection of sunflower hybrids based on stability across environments. Genetika. 2019. Vol. 51. No 1. P. 81-92. DOI: 10.2298/GENSR1901081C.

9. Škorić D., Seiler G. j., Zhao Liu et al. Genetics and breeding of sunflower. Genetics and selection of sunflower. Kharkiv : Serbian Academy of Sciences and Arts. Association «Selection and seed production of sunflower», 2015. $540 \mathrm{c}$.

10. Eberhart S.A., Russel W.A. Stability parameters for comparing varieties. Crop. Sci. 1966. Vol. 6. № 1. P. 36-40.

11. Пакудин, В.3., Лопатина Л.М. Оценка экологической пластичности и стабильности сортов сельскохозяйственных культур. Сельскохозяйственная биология. 1984. № 4. С. $109-113$.

12. Ляшенко Г.В. Агроклиматическое районирование Украины. Украинский гидрометеорологический журнал. 2008. № 3. С. 98-108.

13. Доспехов Б.А. Планирование полевого опыта и статистическая обработка его данных. Москва : Колос, 1972. 207 с.

14. Климатические данные. Электронный ресурс: URL: https://ru.climate-data.org/eвропа /украина.

15. Ляшенко Г.В. Методологические аспекты применения ГИС - технологий при агроклиматическом районировании территорий. URL: http://dspace.nbuv.gov.ua/ bitstream/handle/123456789/98283/30-Lyashenko.pdf? sequence $=1$. 


\section{АДАПТИВНОСТЬ ГИБРИДОВ ПОДСОЛНЕЧНИКА СЕЛЕКЦИИ ВНИС В УСЛОВИЯХ УКРАИНЫ}

Шарыпина Я.Ю., Боровская И.Ю., Парий Я.Ф., Парий Ю.А., Бабич В.О., Наконечная М.С., Костенко Ю.С., Сирко А.С.

ООО «Всеукраинский научный институт селекции», Украина

Цель. Выделение высокоурожайных перспективных гибридов подсолнечника селекции ВНИС для выращивания в определенных регионах Украины.

Материалы и методы. Исследования проводили в 2019 году в восьми областях Украины. Определены параметры экологической пластичности и стабильности гибридов подсолнечника, устойчивых к гербицидам группы имидазолинонов (IMI) и содержащих трибенурон-метил (SU) по урожайности. Обработку экспериментальных данных осуществляли методами вариационной статистики, регрессионного и дисперсионного анализа.

Обсуждение результатов. Разнообразие агроклиматических условий и их распределение в течении года относительно регионов позволило в полной мере выявить потенциал гибридов по урожайности, а также оценить их экологическую пластичность и стабильность по этому признаку. Выделены перспективные гибриды подсолнечника, выявившие высокую урожайность по результатам испытания в восьми пунктах: 2,84-3,43 т/га среди гибридов, устойчивых к гербицидам, содержащих трибенурон-метил (SU) и 2,863,33 т/га - у гибридов, устойчивых к гербицидам группы имидазолинонов (IMI).

Выводы. Перспективные по результатам изучения их экологической пластичности и стабильности гибриды рекомендованы для выращивания в определенных регионах Украины.

Ключевые слова: подсолнечник, гибрид, урожайность, экологическое испьтание, адаптивность, пластичность

\section{АДАПТИВНІСТЬ ГІБРИДІВ СОНЯШНИКА СЕЛЕКЦЇ̈ ВНІС В УМОВАХ УКРАЇНИ}

Шарипіна Я.Ю., Боровська І.Ю., Парій Я.Ф., Парій Ю.О., Бабіч В.О., Наконечна М.С., Костенко Ю.С., Сірко А.С

ТОВ «Всеукраїнський науковий інститут селекції», Україна

Мета. Виділення високоврожайних перспективних гібридів соняшнику селекції ВНІС для вирощування в певних регіонах України.

Матеріали та методи. Дослідження проводили у 2019 році у восьми областях України. Визначено параметри екологічної пластичності і стабільності гібридів соняшнику, стійких до гербіцидів групи імідазолінонів (IMI) та трибенурон - метилу (SU) за урожайністю. Обробку експериментальних даних здійснювали методами варіаційної статистики, регресійного і дисперсійного аналізу.

Обговорення результатів. Різноманіття агрокліматичних умов i їх розподіл впродовж року відносно регіонів дозволило у повній мірі виявити потенціал гібридів за урожайністю, а також оцінити їх екологічну пластичність і стабільність за цією ознакою. Виділено перспективні гібриди соняшника, які виявили високу урожайність за результатами випробувань у восьми пунктах: 2,84-3,43 т/га серед гібридів, стійких до гербіцидів, що містять трибенурон - метил (SU) і 2,86-3,33 т/га - у гібридів, стійких до гербіцидів групи імідазолінонів (IMI).

Висновки. Перспективні за результатами вивчення їх екологічної пластичності і стабільності гібриди рекомендовано до вирощування в певних регіонах України.

Ключові слова: соняшник, гібрид, урожайність, екологічне випробування, адаптивність, пластичність 
Sharypina Ya., Borovska I., Parii Ya., Parii Yu., Babych V., Nakonechna M., Kostenko Yu., Sirko A.

LLC «Ukrainian Scientific Institute of Plant Breeding», Ukraine

Purpose - to select high-yielding promising sunflower hybrids bred at the VNIS for cultivation in certain regions of Ukraine.

Material and methods. The study was carried out in 8 regions of Ukraine in 2019. The environmental plasticity and stability indices of the yield capacity of the sunflower hybrids resistant to tribenuron-methyl (SU)-containing herbicides and imidazolinone (IMI) herbicides were determined. The experimental data were processed by methods of variation statistics, regression and variance analyses.

Results and discussion. The diverse agro-climatic conditions and their distribution during the year in the regions made it possible to fully reveal the yield capacity of the hybrids and to assess their environmental plasticity and stability for this trait. The promising sunflower hybrids were identified. Such hybrids gave high yields during the trials in the eight sites: 2.84-3.43 t/ha from the hybrids resistant to herbicide containing tribenuron-methyl (SU) and 2.86-3.33 t/ha from the hybrids resistant to imidazolinone (IMI) herbicides.

Conclusions. The hybrids, which are promising according to their environmental plasticity and stability, are recommended for cultivation in certain regions of Ukraine.

Key words: sunflower, hybrid, yield, environment trial, adaptability, plasticity 